\title{
Performance of posttensioned seismic retrofit of two stone masonry buildings during the Canterbury earthquakes
}

\author{
Dmytro Dizhur ${ }^{1}$, Sara Bailey ${ }^{2}$, John Trowsdale ${ }^{3}$, Michael Griffith ${ }^{4}$ \\ and Jason M. Ingham ${ }^{5}$
}

1. Research Fellow, Department of Civil and Environmental Engineering, University of Auckland, Private Bag 92019, Auckland, New Zealand, d.dizhur@auckland.ac.nz

2. Student Researcher, Department of Civil and Environmental Engineering, University of Auckland, Private Bag 92019, Auckland, New Zealand, sbai063@aucklanduni.ac.nz

3. Arts Centre Project Director, Holmes Consulting Group, P O Box 6718, Christchurch 8442, New Zealand, JohnT@holmesgroup.com

4. Professor, School of Civil, Environmental and Mining Engineering, University of Adelaide, Adelaide, Australia, mcgrif@civeng.adelaide.edu.au

5. Professor, Department of Civil and Environmental Engineering, University of Auckland, Private Bag 92019, Auckland, New Zealand, j.ingham@auckland.ac.nz

\begin{abstract}
Seismic retrofitting of unreinforced masonry buildings using posttensioning has been the topic of many recent experimental research projects. However, the performance of such retrofit designs in actual design level earthquakes has previously been poorly documented. In 1984 two stone masonry buildings within The Arts Centre of Christchurch received posttensioned seismic retrofits, which were subsequently subjected to design level seismic loads during the 2010/2011 Canterbury earthquake sequence. These 26 year old retrofits were part of a global scheme to strengthen and secure the historic building complex and were subject to considerable budgetary constraints. Given the limited resources available at the time of construction and the current degraded state of the steel posttension tendons, the posttensioned retrofits performed well in preventing major damage to the overall structure of the two buildings in the Canterbury earthquakes. When compared to other similar unretrofitted structures within The Arts Centre, it is demonstrated that the posttensioning significantly improved the in-plane and out-of-plane wall strength and the ability to limit residual wall displacements. The history of The Arts Centre buildings and the details of the Canterbury earthquakes is discussed, followed by examination of the performance of the posttension retrofits and the suitability of this technique for future retrofitting of other historic unreinforced masonry buildings.
\end{abstract}

Keywords: Posttensioning, Rehabilitation, Masonry, Earthquake resistant structures 


\section{INTRODUCTION}

Unreinforced masonry (URM) buildings are known to perform poorly in large earthquakes, as previously demonstrated in New Zealand in the 1931 Hawke's Bay earthquake (Dowrick 1998 and Russell and Ingham 2010) and in many other significant earthquakes worldwide. As a result of the extensive and well publicized damage to URM buildings in the 1931 Hawke's Bay earthquake, construction of URM buildings in New Zealand rapidly declined and was eventually prohibited. Therefore, most of New Zealand's URM building stock was constructed prior to 1935 and was typically designed with little or no consideration for lateral loads (Senaldi et al. 2013). In response to these historical factors, the New Zealand Building Act 2004 requires territorial authorities to adopt policies on strengthening or demolishing of earthquake prone buildings. As many historic URM structures are considered to be either 'earthquake prone' (satisfies 1/3 of current earthquake loading standard) or 'earthquake risk' (satisfies 1/3 to 2/3 of current earthquake loading standard) (Russell and Ingham 2010) these buildings must be either seismically retrofitted or demolished in the near future (NZSEE 2006), with the former scenario being favourable as many of these URM buildings are listed on the Register of the New Zealand Historic Places Trust.

Posttensioned Masonry (PTM) is a seismic retrofit option that has received increasing attention since the 1950's (Bean Popehn et al. 2007a). PTM combines the high compressive strength of masonry with the modern construction technique of posttensioning, and involves the addition of tendons (typically steel) either placed inconspicuously in corners and at other discrete locations external to a masonry wall, or by drilling ducts down the centre of existing masonry walls and installing the tendons internally within the wall. The tendons are anchored at the base of the masonry wall and pulled into tension at the wall top using a hydraulic jack. This procedure results in the masonry being loaded into compression by the tendons, offsetting any tensile stresses experienced under service conditions (Bean Popehn et al. 2007b). The compressive force enhances the strength, cracking behaviour and ductility of the masonry walls, as well as having a restoring or self-centering effect, reducing residual deformations after loading (Schultz and Scolforo 1991, Ganz 2003, Bean Popehn et al. 2007a and Ma et al. 2012). Posttensioning as a seismic retrofit method is also advantageous as the procedure involves no substantial mass increase, fully utilises the current structure, and is relatively simple and economical to install (Ma et al. 2012).

International research has primarily focused on the out-of-plane behaviour of PTM, as out-ofplane wall failure is typically more common and occurs earlier in a large earthquake than does in-plane wall failure, as widely demonstrated in the 2010/2011 Canterbury earthquakes (Dizhur et al. 2010). PTM is therefore generally used to enhance the out-of-plane characteristics of URM structures and enable their shear capacity to be fully utilised (Ma et al. 2012). However in the case of The Arts Centre, posttensioning was primarily used to enhance the in-plane capacity and prevent rocking of columns and buttresses, as the walls are sufficiently wide to reduce the likelihood of out-of-plane wall failure.

Internationally, posttensioning has previously been used in a number of retrofits such as the Holy Cross Church in Santa Cruz, The General Post Office Tower in Sydney and The Los Gatos Brick Castle (Ganz 1993). However, observations on the performance of such retrofits in an actual design level earthquake have not previously been reported. Therefore, the Canterbury earthquake sequence has provided a unique opportunity to compare the actual 
performance of the posttensioned seismic retrofit of two buildings in the Christchurch Arts Centre against previously determined laboratory experimental results.

\section{HISTORY OF THE CHRISTCHURCH ARTS CENTRE}

The Arts Centre of Christchurch (TAC) is located near the centre of Christchurch city and is encompassed by Montreal and Hereford St, Rolleston Ave and Worcester Boulevard. The centre occupies 2.25 hectares (Le Couteur 2012) and was the original grounds of Canterbury College, Christchurch Girls’ and Christchurch Boys’ High Schools and latterly the University of Canterbury. The area occupied by TAC was incrementally populated with buildings as Canterbury College grew to accommodate the increasing population of Christchurch. The current layout of the Arts Centre complex is shown in Figure 1.

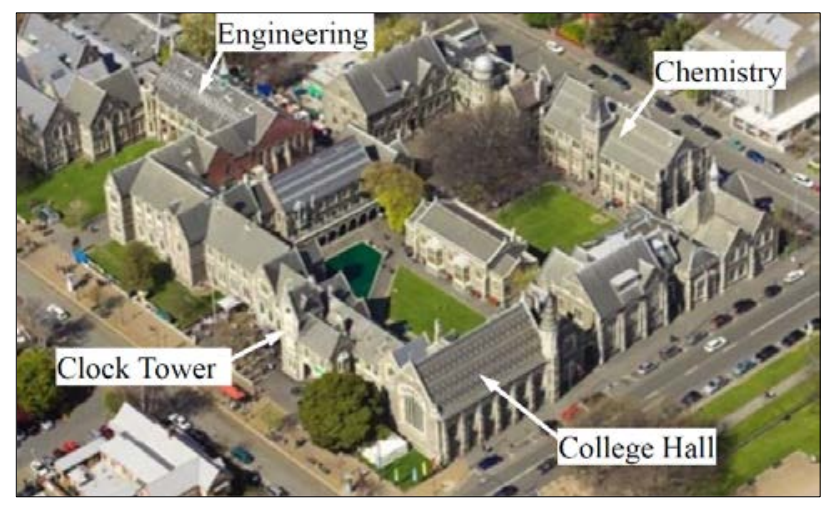

Figure 1: Layout of Christchurch Arts Centre prior to Canterbury earthquakes (modified from www.davidwallphoto.com)

The first building to be completed at TAC site was the Clock Tower block in 1877. Designed by Benjamin Mountfort, the Clock Tower is High Victorian Collegiate Gothic, which was a common style for churches and university buildings in England at the time. The Clock Tower was built of basalt from Christchurch's Port Hills and of limestone from Coal Creek, Pleasant Point, and housed offices, professors' studies, a mathematics lecture room, board room, and the women's common room (Strange 1994).

Following the construction of the original Canterbury College Clock Tower building in 1878, Mountfort also designed the College Hall that was completed in 1882. All of these buildings followed the precedent style set by earlier construction (Strange 1994). In 1890 Ernest Rutherford arrived at Canterbury College Christchurch as the $338^{\text {th }}$ registered student, before graduating in 1885 with his BA, MA and MSc and continuing his postgraduate studies at the University of Cambridge, following which he received numerous awards throughout his academic career including a Nobel Prize for Chemistry in 1908.

Collins and Harman designed the remaining stone buildings of Canterbury College which were completed between 1910 and 1929, including the Chemistry building in 1910. After completion of these remaining buildings, it was obvious that further expansion would be required. The university made the decision to move to the Ilam campus on the edge of the city, with the School of Art being the first to relocate in 1957. By the 1970's, the University of Canterbury had completely vacated the central city site and in 1973 it was officially announced that the old school grounds would be given to the city as an Arts Centre. 
In 1990 the buildings (excluding the Student Union building) were classified as Category 1 Historic Places recognising the importance of not just the individual buildings, but the complex as a whole as it contributed to education and reflected the early settlers' intention to create a campus similar to that of Oxford and Cambridge (New Zealand Historic Places Trust 2001). A conservation plan was also initiated and earthquake strengthening had already begun, leading to posttensioned seismic retrofitting of the Chemistry building and Great Hall. Prior to the Canterbury earthquakes, the Arts Centre was alive with activity and home to numerous cafes, cinemas, shops, restaurants, markets, artists, the Southern Ballet and the Court Theatre. Following the earthquakes all of these entities have vacated the site while the buildings undergo repair and further strengthening (The Arts Centre 2012).

\section{RETROFIT DETAILS}

The posttensioned seismic retrofit of the Chemistry and College Hall buildings (see Figure 2) was designed by engineer Brian Wood and carried out under the supervision of building manager Jim Loper, and was completed in 1984. The retrofits were part of a global strengthening and securing scheme and were limited by budgetary constraints, with the intention of further earthquake strengthening being applied as funds became available. The decision to utilise posttensioning was influenced by a variety of factors. The designer's intention was to utilise as much of the inherent capacity of the building shell as possible by increasing the strength of the structural elements and maintaining the original, predictable load paths. As mentioned previously, posttensioning is effective in fully utilising the inherent capacity of the original masonry structure when loaded in compression (Ma et al. 2012). The technique was also a relatively cheap alternative to other options and was being installed in other applications around New Zealand at the time (Hanlon 1970), including prestressed concrete being incorporated by Lyall Holmes (a colleague of Brian Wood) in the new University of Canterbury buildings at the Ilam campus (Reitherman 2012).

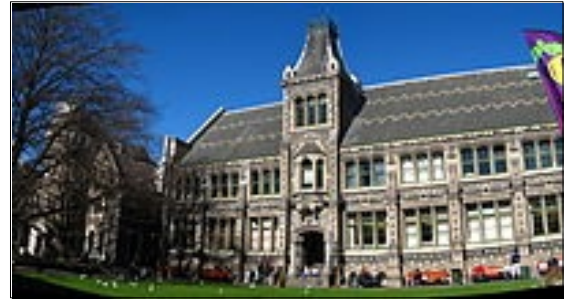

a) Chemistry Building

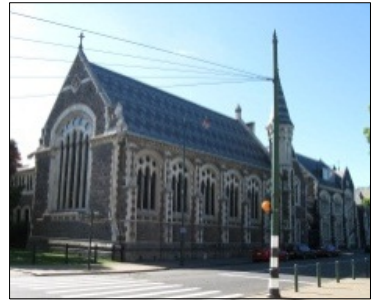

b) Great Hall

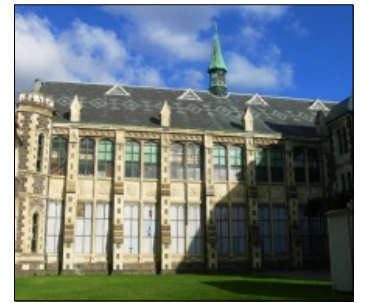

(c) Engineering building

Figure 2: Chemistry building and Great Hall prior to Canterbury earthquake sequence

\section{Retrofit of the Chemistry building}

The Chemistry building (see Figure 2a) is constructed of Hallswell basalt walls with Oamaru stone facings. Hallswell basalt is a strong volcanic stone, while Oamaru stone is easily carved to produce decorative features. There are four storeys to the lone standing Chemistry building, a look-out basement, ground level, first floor and attic level. The entrance to the building is at the centre of the northern side and is beneath the chemistry tower which separates the two symmetrical ends of the building. The Chemistry building is one of the few structures at TAC site that stands alone and has not been connected to other extensions over the years. 
The retrofit to the Chemistry building (as shown in Figure 3) was part of a strengthening scheme that also involved diaphragm strengthening and steel frames being applied to the attic level (see Figure 4, also, illustrated by dotted lines in Figure 3a). Vertically oriented posttension tendons were installed on the ground level along the north and south facades. These tendons were located in pairs on either side of the buttresses and were anchored into the concrete slab above the basement, stretching up to the bottom of the top level of the building (Figure 4). In total, seven pairs of vertically oriented tendons were installed on both the north and south faces. Horizontally oriented posttension tendons were also applied on the north and south faces of the building, and were paired with a companion tendon running parallel on the inside of the wall in order to enhance a frame-type action of building response. Two pairs of horizontally oriented tendons were applied to the north and south faces, one at the base of the ground level and one at the base of the first floor level.

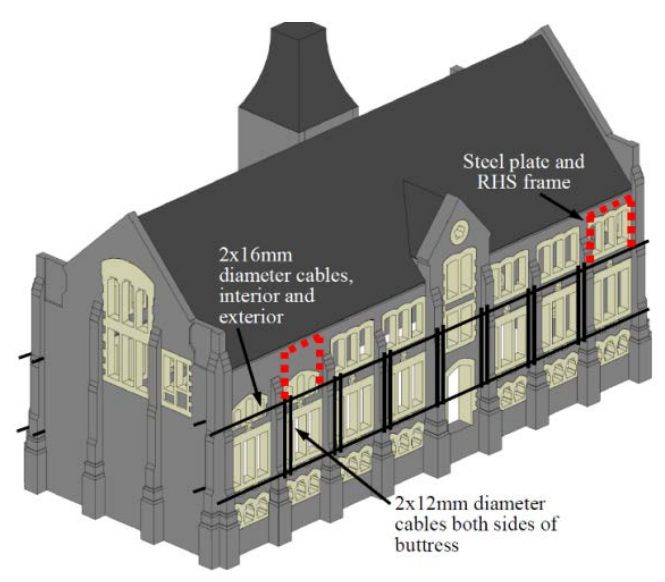

(a) Isometric view of the building showing the location and the extent of the retrofit

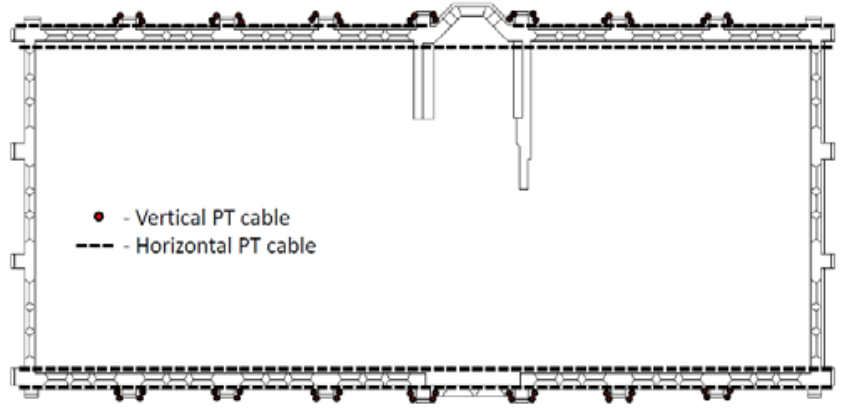

(b) Floor plan of the building showing location and the extent of the retrofit

Figure 3: Chemistry building

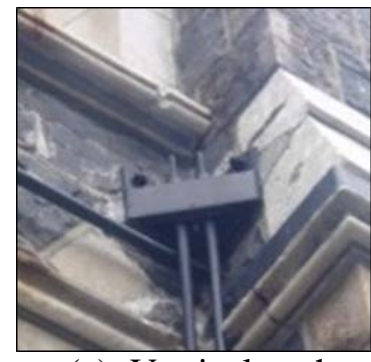

(a) Vertical anchors

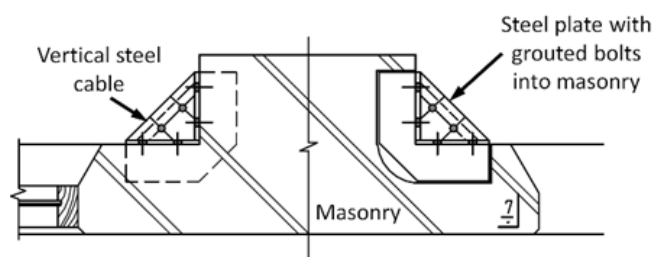

(b) Schematic of vertical anchors

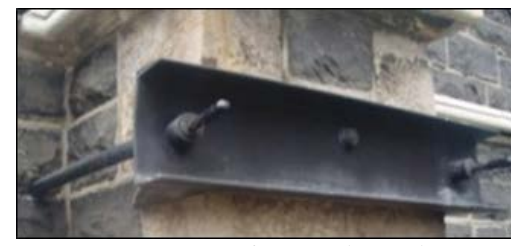

(c) Horizontal anchor

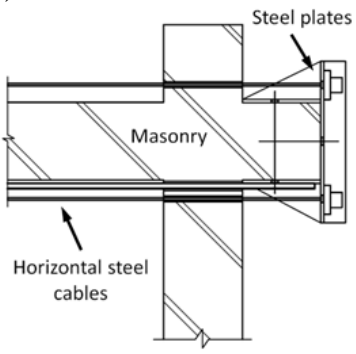

(d) Schematic of horizontal anchor

Figure 4: Posttensioned seismic retrofit of the Chemistry building 
The posttensioned seismic retrofit of the Chemistry building was only applied to the ground storey as the first floor of the Chemistry block had an irregular configuration and so was less suited to posttensioning. The building also had a good sarked timber roof diaphragm, so tying together and installing steel frames was considered sufficient to support the upper level of masonry. The east and west faces of the building were left without retrofit, with the intent being for these walls to act as conventional URM shear walls. The tower was also left without significant seismic strengthening, resulting in the poor performance of this building element during the Canterbury earthquakes.

\section{$\underline{\text { College Hall retrofit }}$}

The College Hall is an open space, 24.4 metres long and 9.15 metres wide, with the interior reaching 13 metres in height. The College Hall wall construction is comprised of basalt rock and an Oamaru stone exterior, with a combination of red brick masonry and Ashlar (fine grain Oamaru stone) interior. The central core, between these inner and outer layers, is a poorly consolidated cementitious concrete and rubble fill. The interior of the College Hall is comprised of a variety of decorative timber, including Kauri, Rimu and Kahikatea which are all timber species native to New Zealand. The College Hall is part of a disjointed group of buildings that has been incrementally connected to others as extensions were made.

The College Hall posttensioned seismic retrofit was applied to the west side of the building (Figure 5 and 6) and was completed in conjunction with window frame strengthening and widening of the foundations for stability once the posttensioning was applied. The exterior posttension tendons extended from the new foundations to wall mid-height, while the interior posttension tendons extended from the foundation to the roof truss (see Figure 6). The exterior tendons were located in pairs on either side of the buttresses, while the internal tendons were in groups of three, again located on the internal side of each buttress as indicated in Figure 5b. The posttensioned retrofit was applied to compensate for the ineffectiveness of the roof diaphragm in the east/west direction. Therefore the walls were designed as cantilevers and during the retrofit grout was pumped into the drilled holes around the piers in order to fill any voids within the piers.

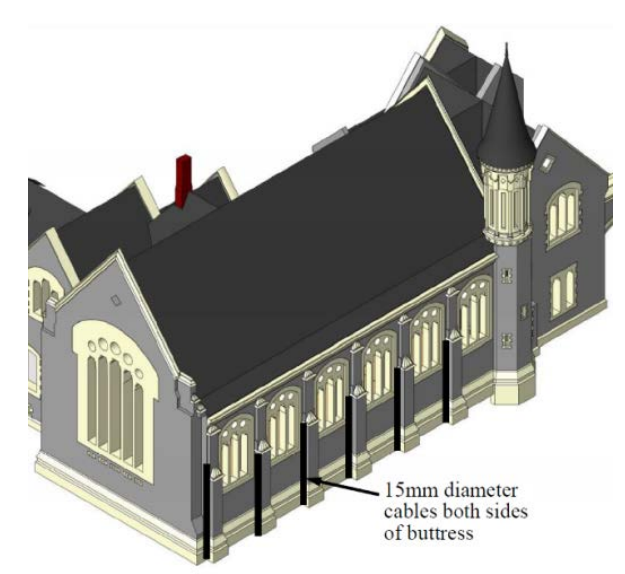

(a) Isometric view of the building showing the location and the extent of the retrofit

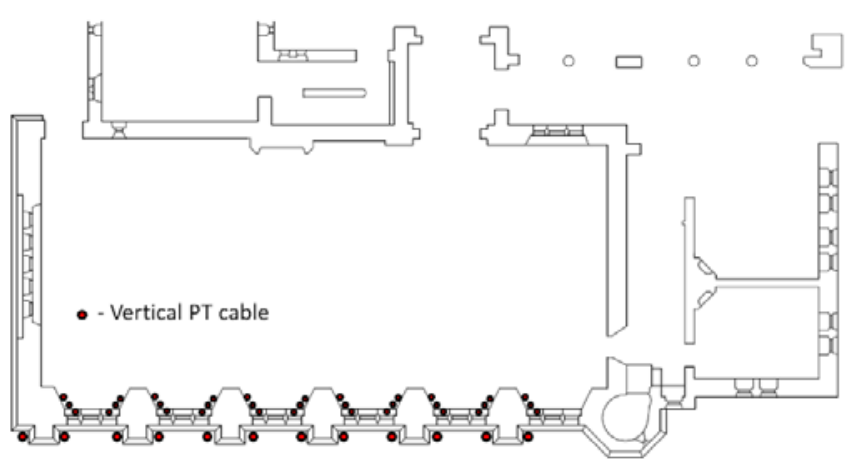

(b) Floor plan of the building showing the location and the extent of the retrofit

Figure 5: College Hall building 


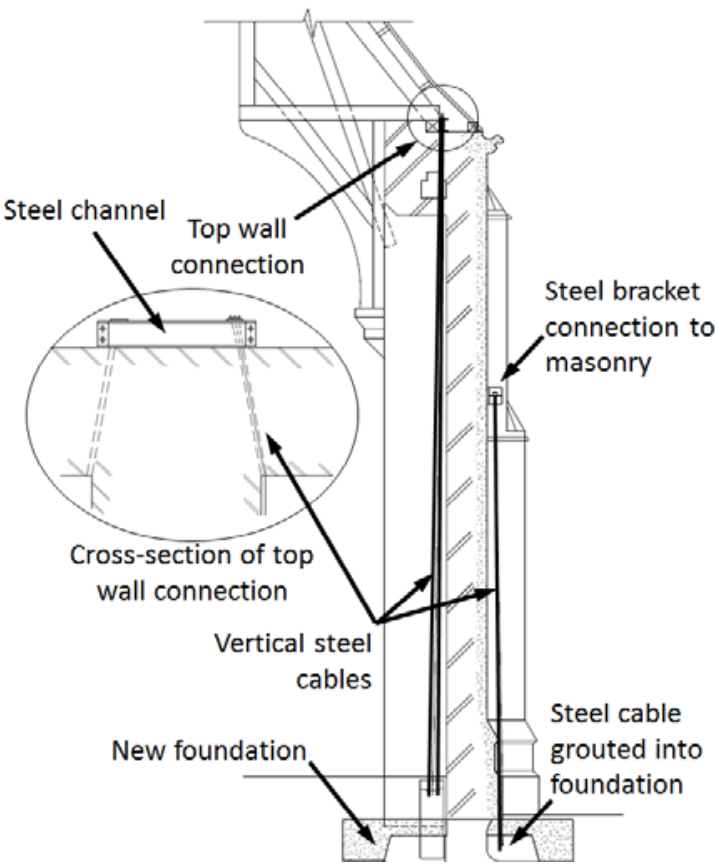

(a) Great Hall retrofit cross-section (redrawn from original)

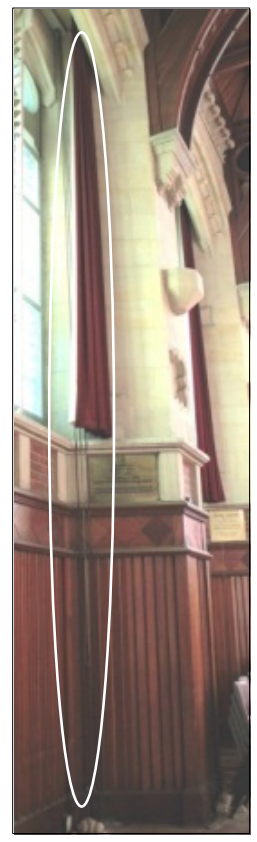

b) Internal PTSide view

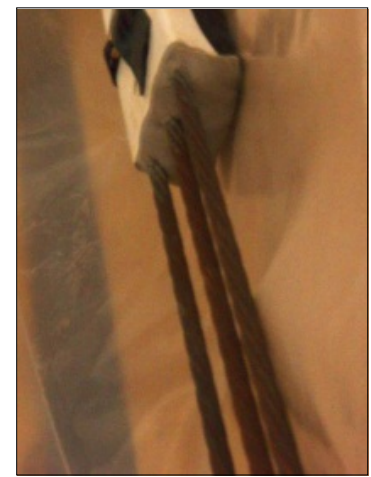

c) Groups of three tendons

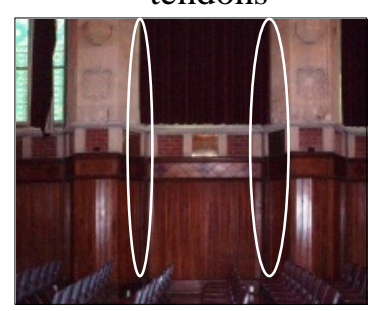

d) Internal PT-Front View

Figure 6: Great Hall retrofit cross-section and condition of the interior posttensioning within the Great Hall following the Canterbury earthquakes

The exterior tendons of the College Hall retrofit only extended to wall mid-height due to two factors. The design of the external face has the buttresses progressively stepping back towards a plain wall (as shown in Figure 6a), and had the tendons been extended, than the neutral axis would have been outside the centre third of the cross-section. The second factor related to the difficulty of fixing the tendons to the roof truss and the significant cost of removing the roof slates that would have required for this anchoring detail.

Posttensioned strengthening was only applied to the west facade of the College Hall due to the pier-spandrel construction of this face, which allowed the efficient and economical installation of the tendons. The west facade was identified as the weaker aspect of the building and therefore the limited funds available were allocated to this strengthening. Although it was identified that other areas of the building could also benefit from seismic strengthening, the limited funds available resulted in further strengthening being delayed until more funding was available.

The corrosion of tendons was considered for both buildings by greasing the steel cables and covering the tendons with PVC ducts, as previously adopted by Hanlon (1970). It is noted that corrosion was not a major consideration during the design of the retrofit, and that the design life of the tendons was not critically assessed due to the intent that given more funds, TAC complex would receive further seismic improvements and these retrofits would be improved as additional resources became available. However, this improvement never occurred and during post-earthquake inspection no evidence of grease was found on the cables.

The posttension tendons of both the Chemistry building and the College Hall were stressed to standard levels and losses were subsequently not considered further. As a result, the only 
consideration was that if in the future the tendons were observed to be slacking, then they would be inspected and consequently re-stressed.

\section{THE CANTERBURY EARTHQUAKES}

The Canterbury earthquake sequence that began on the 4th September 2010 at 4.35am has been the cause of much destruction and loss of life (Canterbury Earthquakes Royal Commission 2011). The initial earthquake was magnitude M7.1 and located $40 \mathrm{~km}$ west of Christchurch city at a depth of $10 \mathrm{~km}$ (GNS 2010). The overall performance of buildings during this first earthquake was relatively good, with most damage observed in URM buildings such as those of the Christchurch Arts Centre (Ingham and Griffith 2011). A subsequent significant earthquake occurred on 22nd February 2011. This shake, although consisting of a lower magnitude of M6.3, was located only 6-10 km south-east of Christchurch city and at a shallow depth of $5 \mathrm{~km}$ (GNS 2011). The closer location and surface proximity of the 22 February 2011 earthquake resulted in larger ground accelerations and more significant structural damage to all building types when compared to the 4 September 2010 earthquake (Dizhur et al. 2011). The February tremor, although of shorter duration, had peak ground accelerations (PGA) equivalent to or of greater intensity than considered in new building design standards. Christchurch Hospital (CHHC) station was identified as the closest strong motion recording station to the Christchurch Arts Centre and recorded peak ground acceleration (PGA) of 0.37g (Bradley et al. 2013). The design level PGA at the time of the earthquake was equivalent to $0.36 \mathrm{~g}$ (NZS 1170.5:2004). It is believed that the design GPA used at the time of the design was $1 / 2$ of $0.42 \mathrm{~g}$ the earthquake loading code at the time (NZS 4203:1976).

Accompanying these two major events in September 2010 and February 2011 have been thousands of aftershocks causing further damage to buildings already made vulnerable during the larger shocks. Of significance were the 13 June 2011 and 23 December 2011 events, both of which were $7 \mathrm{~km}$ deep and originated $10 \mathrm{~km}$ east of Christchurch. The extent of the aftershock activity can be viewed in detail at Canterbury Quake Live (Crowe 2012).

Due to the constant seismic activity, a number of research projects were undertaken to document the performance of unreinforced clay brick and stone masonry buildings during the Canterbury earthquakes. Project Masonry (Dizhur et al. 2010 and Dizhur et al 2011) was focused on documenting the performance and common failure mechanisms of masonry buildings in the Christchurch area, as well as inspecting the performance of different seismic retrofit techniques in Christchurch URM buildings and their variable success during the earthquake sequence. Senaldi et al. (2013) reported on the performance of stone masonry buildings and churches similar to and including the Christchurch Arts Centre.

\section{PERFORMANCE OF PTM SEISMIC RETROFITS}

The posttensioned retrofits of the Chemistry and College Hall buildings improved the global seismic performance of these structures during the Canterbury earthquakes. Given the age and condition of the tendons (Figure 7a), the retrofits outperformed the expectations of structural engineers responsible for oversight of the TAC complex. Having never been restressed following original installation and with no consideration ever given to the extent of prestress losses, it is also likely that the level of prestress within the tendons had significantly decreased since first installation. All except one vertically oriented tendon in both buildings 
remained intact, with the vertical tendon that failed being part of the College Hall retrofit and being the southern external tendon on the 4th buttress from the northern side of the building. Damage surveys were completed on the TAC complex after the February 2011 earthquake. The damage to the Chemistry building was significant due to failure of the tower above the main entrance, which was subsequently removed. External damage to the Chemistry building was primarily to gables and the main tower, with some minor superficial cracking and loss of stonework at Level 1. As the tower had only received nominal securing, this outcome was to be expected. Gables also performed poorly due to inadequate connection to the roof and low stiffness of the adjacent strengthened flexible diaphragm. The overall structure performed well, particularly at ground level where the posttensioning was applied. Nearly all of the stone damage, broken windows and minor cracking occurred during the 22 February 2011 earthquake due to greater peak accelerations which exceeded current design levels.

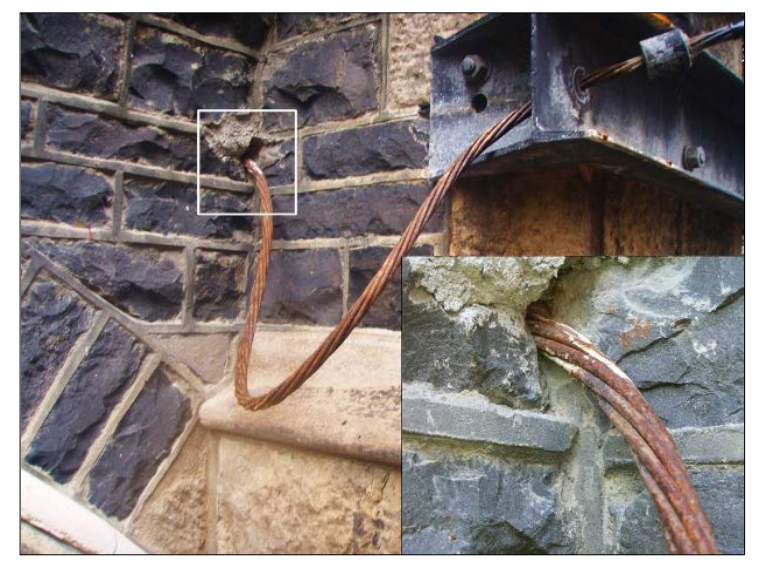

(a) Corrosion of PT steel (after tendon had been released to enable strengthening works)

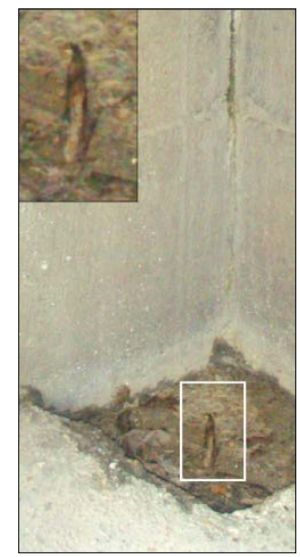

(b) Area where pond of water was able to form around failed tendon

Figure 7: Corrosion of PT steel

Internal damage to the Chemistry building was again predominantly to the tower. However, some cracking was identified, indicating differential movement of connecting elements. This differential movement was particularly evident on the top level when compared to the ground level where the posttensioned seismic retrofit was applied.

In the post-earthquake process of repairing the Chemistry Tower, the lower pairs of horizontally oriented tendons on the North façade were released for construction purposes. During this process it was identified that upon release, all of the tendons had some minor to moderate damage concentrated at the steel anchorages. Although unmeasured, it was also noted that the four horizontally oriented tendons that were released had significant prestress levels remaining.

External damage to the College Hall during the 22 February 2011 event was restricted to the east side of the building, as well as around the dominant window feature on the North face. The damage was consistent with insufficient connection between the roof and the gables, reduction and lack of diaphragm stiffness (Figure 8), as well as differential movement between jointed structures on the east side of the building. Damage was also sustained to the turret during the September earthquake, which was subsequently removed prior to February 22. During the first earthquake in September 2010 the posttension tendons were approximately 26 years old and in most cases a minor to moderate extent of corrosion was observed, as indicated in Figure 7a. The condition of the tendons across the site ranged from 
minor surface flecking to significant loss of cross section, dependant on the location within the structure and the environmental exposure. The exterior west side of the building where the posttension tendons were applied performed well, with almost no damage except the failure of one tendon. The cross-section of the failed tendon was significantly reduced at the point of failure, most likely due to the design of the lower anchorage effectively creating a pond around the tendon during wet conditions (Figure $7 \mathrm{~b}$ ), resulting in constant wetting and drying causing corrosion and deterioration of the tendon. Similar damage to the tendons was identified along the length of the wall, but because inspections were only undertaken postearthquake, it is unknown whether the failed tendon ruptured as a result of the earthquake or had already failed due to the section reducing to an area that was unable to sustain the imposed prestress. Giving consideration to the exposure of the tendons, a limited warranty to such a design would be granted given the current stringent durability requirements. Therefore, for a long-term solution, some further form of protection would be necessary, and given the 26 year old age of the tendons it is concluded that they performed well in the environmental conditions that they were exposed to.

Internal damage to the College Hall was generally sustained at level 1 or above, suggesting that the PT was effective in preventing damage at lower levels. Again, the damage was restricted to where the timber roof trusses connected to the walls (Figure 8), as well as in locations where adjoining extensions had been added on. Apart from some slight movement of one window on the retrofitted side of the building, little damage was evident, which can be attributed to the successful performance of the posttension retrofit.

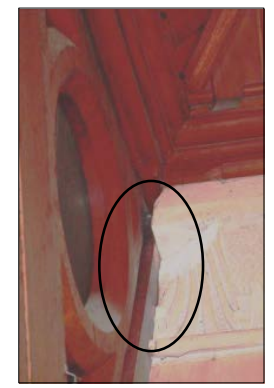

a) Spalling of Ashlar and out-ofplane movement at timber truss connection

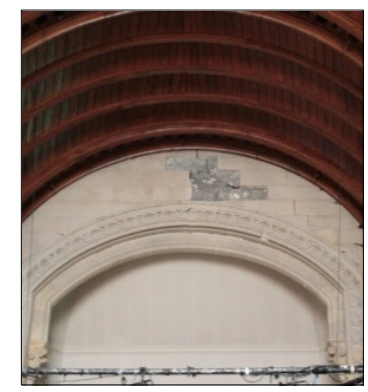

b) Damage to gable due to inadequate connection between timber roof and gable top

Figure 8: Damage to interior of the Great Hall

Quantifying the performance of the posttension retrofit is difficult, but by comparing the damage to the retrofitted Chemistry building with that of the un-retrofitted Engineering building, key advantages of the posttensioning can be identified. The Engineering building is of similar pier/spandrel construction with a slightly different aspect ratio, but overall provides the best comparison available at the Arts Centre site. A visual comparison of the Chemistry building versus the Engineering building can be seen in Figures 9. The Engineering building suffered from out-of-plane movement indicated by the formation of hinges due to rocking at the top and bottom of the second level (Figures 9a and 9b respectively). At the Chemistry building no evidence of hinge formation at the piers as is evident for the Engineering building. The mortar of the Chemistry building is still intact, indicating that the posttension tendons limited tensile forces that developed in the masonry, minimising any hinging between the masonry units and mortar as shown in Figure 9. Unlike the retrofitted Chemistry building, there was also significant permanent deformation of the second level of the Engineering building as shown by the large overhang in Fig 9c. No identifiable permanent deformation at 
the Chemistry building was identified. This comparison identifies the favourable restoring ability of the posttension seismic retrofit.
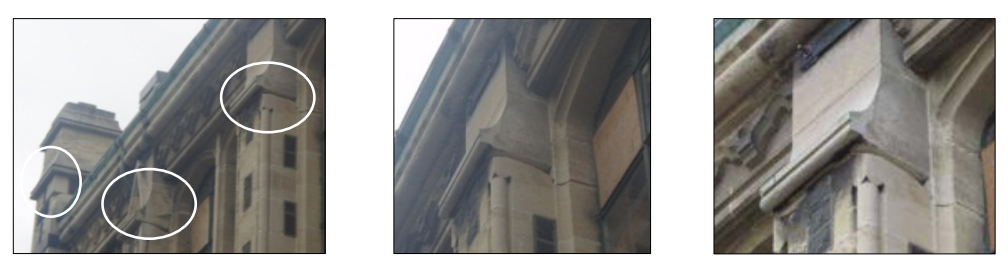

a) Hinge formation
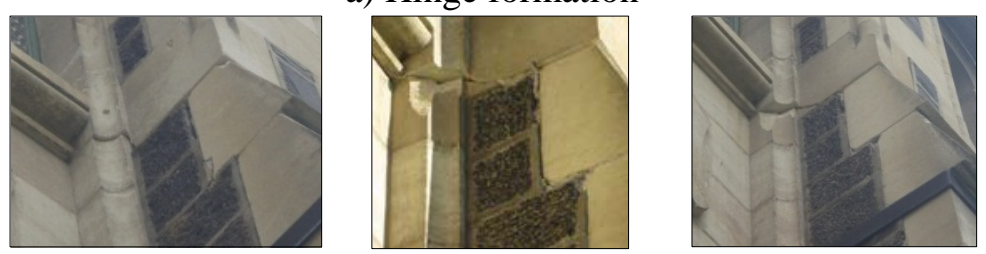

b) Loss of mortar - evidence for hinge formation
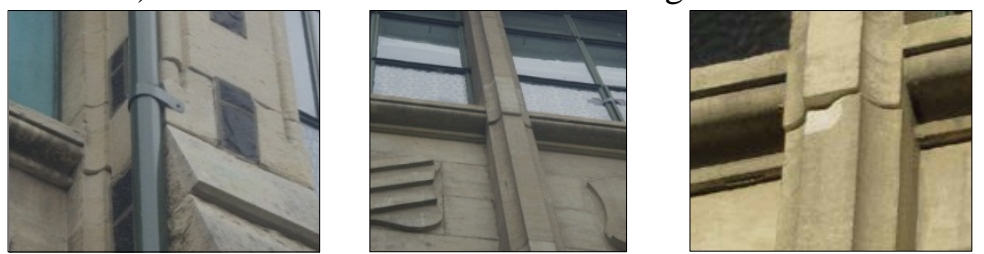

c) Residual displacements

Figure 9: External failures of the Engineering building

Figure 10 shows the damage to the interior of the Engineering building, again highlighting the out-of-plane rocking and differential movement that occurred throughout the unretrofitted building. Although the Chemistry building also suffered some internal cracking, the extent of the damage and therefore repairs needed was minimal compared to that of the Engineering building. Based on observations alone it can be concluded that the retrofit of the Chemistry building provided improvements in the out-of-plane loading direction as well as addressed in-plane deficiencies as initially intended with the retrofit design scheme.

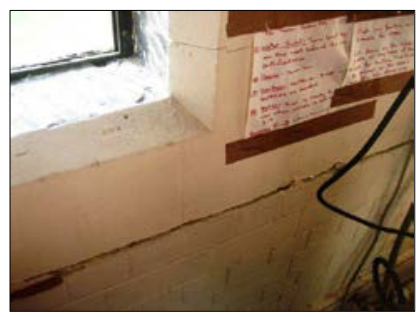

a) Out-of-plane rocking resulting in residual displacement along North elevation of $10 \mathrm{~mm}$

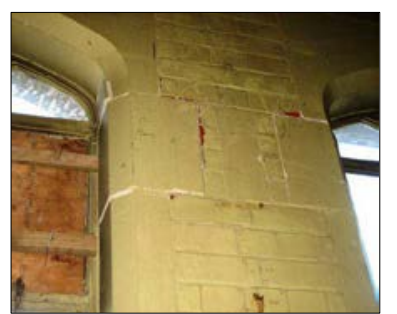

b) Differential movement between North Elevation buttresses and roof diaphragm

Figure continued over page 


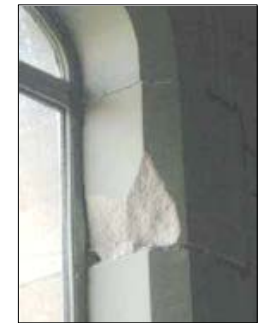

c) Same as (b)

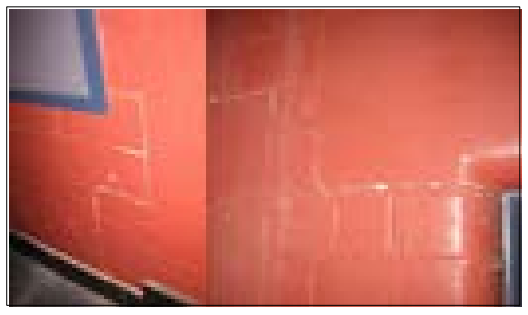

d) Ground floor - evidence of differential movement, spalling of mortar and residual displacement common at this level

Figure 10: Internal failures of the Engineering building

The cost benefits of the posttension seismic retrofit are also difficult to quantify. However, based on the minimal earthquake damage requiring repair and the total site-wide insurance pay-out following the Canterbury earthquakes, the value of the reduced earthquake damage is expected to exceed NZ\$1 million. Due to significant permanent deformation and dislodgement of the piers in the Engineering building, the repair cost is expected to be significant (actual values are unknown at the time of writing). Of greater value is the known satisfactory performance of PTM as a viable retrofit strategy, resulting in excess of 480 linear metres of new PTM being introduced to the Clock Tower and College Hall buildings during post-earthquake damage remediation.

Due to the favourable performance of the posttension tendons, the existing seismic retrofits are in the process of being renewed. The tendons of the Chemistry building are being replaced with stainless steel material to prevent corrosion and the tendons of the Great Hall are being removed from sight and instead ducts are being drilled within the wall to install new tendons, thus preserving the architectural characteristics, protecting the tendons from environmental conditions, and satisfying the elevated post-earthquake seismic improvement criteria for historic buildings in Christchurch.

\section{CONCLUSIONS}

The 1984 posttensioned seismic retrofits of the Chemistry and Great Hall buildings of the Christchurch Arts Centre have been reviewed and discussed. Previously there has been an absence of documented information on the performance of posttensioned seismic retrofits in an actual earthquake and the Canterbury earthquake sequence has provided an ideal opportunity to remedy this deficiency.

The performance of the posttensioned seismically retrofitted building versus other unretrofitted buildings in the Arts Centre was compared, highlighting the favourable performance of posttensioned stone masonry and its lateral displacement restoring capabilities, preventing excessive out-of-plane rocking and hinge formation. Although both posttension retrofitted buildings sustained moderate damage during the earthquake sequence, the overall performance of these structures was favourable when compared to the performance of other Arts Centre buildings that had not been retrofitted, resulting in significant cost benefits. In locations within the buildings where the posttension tendons had been applied there was little damage in comparison to other un-retrofitted areas within the same building, again indicating the favourable performance of the posttension retrofits. 
However, it must also be acknowledged that these retrofits were subject to budgetary constraints and that they were undertaken as part of a global scheme that also included other strengthening and securing techniques. Given the age and stress condition of the tendons, the performance of the posttensioned seismic retrofit exceeded the expectations of the professional structural engineers responsible for the complex. It can be concluded that the posttensioned seismic retrofits, as previously determined in various laboratory experiments, positively contributed to enhancing the seismic performance of the two retrofitted buildings.

\section{ACKNOWLEDGEMENTS}

The authors wish to thank The Arts Centre of Christchurch for allowing access and information to be provided during a busy and difficult time of post-earthquake reconstruction. In addition, the helpful insight of original design engineer Brian Wood as well as the structural engineers at Holmes Consulting Group in Christchurch that assisted in the collection of resources and provided their expert opinion in assessing the buildings involved is greatly appreciated. Finally, Ilaria Senaldi is thanked for photographic contributions.

\section{REFERENCES}

Bean Popehn, J. R., Schultz, A. E., and Drake, C. R. (2007a). "Behavior of Slender, Posttensioned Masonry Walls under Transverse Loading." Journal of Structural Engineering 133 (Special Issue: Precast-Prestressed Concrete Structures under Natural and Human-Made Hazards): 1541-1550.

Bean Popehn, J. R. (2007b). "Post-tensioned masonry: the positive effects of stress" Masonry Construction, The World of Masonry, 20(2): 34-39.

Bradley, B.A, Quigley, M.C., Van Dissen, R.J., and Litchfield, N.J. (2013). "Ground Motion and Seismic Source Aspects of the Canterbury Earthquake Sequence.” Earthquake Spectra (in press)

Building Act 2004 (2004), Department of Building and Housing - Te Tari Kaupapa Whare, Ministry of Economic Development, New Zealand Government, Wellington, New Zealand, Date of assent: 24 August 2004.

Canterbury Earthquakes Royal Commission (2011). http://canterbury.royalcommission.govt.nz/

Crowe, C. (2012). "Canterbury Quake Live." Retrieved 17 Dec 2012, from http://www.canterburyquakelive.co.nz/.

Dizhur, D., Ingham, J. M., Moon, L., Griffith, M., Schultz, A. E., Senaldi, I., Magenes, G., Dickie, J., Lissel, S., Centeno, J., Ventura, C., Leite, J., and Lourenco, P. (2011). "Performance of Masonry Buildings and Churches in the 22 February Christchurch Earthquake", Bulletin of the New Zealand Society for Earthquake Engineering, 44, (4): 279-297.

Dizhur, D., Ismail, N., Knox, C., Lumantarna, R., and Ingham, J. M. (2010). "Performance of Unreinforced and Retrofitted Masonry Buildings during the 2010 Darfield Earthquake." Bulletin of the New Zealand Society for Earthquake Engineering 43(4): 321-339.

Dowrick, D. (1998). "Damage and Intensities in the Magnitude 7.81931 Hawke's Bay, New Zealand, Earthquake." Bulletin of the New Zealand National Society for Earthquake Engineering, 31(3): 139-163.

Ganz, H. R. (1993). Strengthening of Masonry Structures with Post-tensioning. Proceedings of the Sixth North American Masonry Conference, Philadelphia, PA.

Ganz, H. R. (2003). "Post-Tensioning Masonry Around the World." Concrete International 25(1): 6569. 
GNS. (2010). "M 7.1, Darfield (Canterbury), 4 September 2010." Retrieved 17 Dec 2012, from http://info.geonet.org.nz/display/quake/M+7.1\%2C+Darfield+\%28Canterbury\%29\%2C+4+Sep tember+2010.

GNS. (2011). "M 6.3, Christchurch, 22 February 2011." Retrieved 17 Dec 2012, from http://info.geonet.org.nz/display/quake/M+6.3\%2C+Christchurch\%2C+22+February+2011.

Hanlon, J. R. G. (1970). "Concrete Masonry in New Zealand: pre-stressed concrete masonry." Concrete. The Concrete Society (England) 4(9): 356-358.

Ingham, J. M., and Griffith, M. (2011). "Performance of Unreinforced Masonry Buildings During the 2010 Darfield Christchurch NZ Earthquake." Australian Journal of Structural Engineering 11(3)

IPENZ. (2011). "Christchurch Earthquake Fact Sheets." Retrieved 17 Dec 2012, from http://www.ipenz.org.nz/ipenz/forms/pdfs/ChChFactSheets-Overview.pdf.

Ismail, N. and Ingham, J. M. (2012). "Cyclic Out-of-Plane Behavior of Slender Clay Brick Masonry Walls Seismically Strengthened Using Posttensioning." Journal of Structural Engineering 138(10): 1255-1266.

Laursen, P. T., and Ingham, J. M. (2004). 'Structural Testing of Large-Scale Post-Tensioned Concrete Masonry Walls' ASCE Journal of Structural Engineering, 130(10): 1497-1505.

Le Couteur, C. (2012). "A Unique Complex." Engineering Insight 13(1): 17-19.

Ma, R., Jiang, L., He, M.. Fang, C., and Liang, F. (2012). "Experimental Investigations on Masonry Structures using External Prestressing Techniques for Improving Seismic Performance." Engineering Structures 42(10): 297-307.

New Zealand Historic Places Trust (2001). "1-3 Hereford Street, 2-28 Worcester Boulevard and 26 Rolleston Avenue." Retrieved 14 Dec 2012, from http://www.historic.org.nz/TheRegister/RegisterSearch/RegisterResults.aspx?RID=7301.

NZS (2004) “NZS 1170.5:2004 Structural Design Actions, Part 5-Earthquake Actions New Zealand,” Standards New Zealand.

NZS (1976) "NZS 4203:1976 Code of Practice for General Structural Design and Design Loadings for Buildings," Standards New Zealand.

NZSEE (2006). Assessment and Improvement of the Structural Performance of Buildings in Earthquakes - Recommendations of a NZSEE Study Group on Earthquake Risk Buildings, New Zealand Society for Earthquake Engineering.

Reitherman, R. (2012). Earthquakes and Engineers, An International History. Reston, Virginia, American Society of Civil Engineers.

Russell, A. P. and J. M. Ingham (2010). "Prevalence of New Zealand's Unreinforced Masonry Buildings." Bulletin of the New Zealand Society for Earthquake Engineering 43(3): 182-201.

Schultz, A. E. and Scolforo, M. J., (1991). "An Overview of Prestressed Masonry." The Masonry Society Journal, 10(1): 6-21.

Senaldi, I., Magenes, G., and Ingham, J. M. (2013) "Damage Assessment of Unreinforced Stone Masonry Buildings After the 2010-2011 Canterbury Earthquakes.", International Journal of Architectural Heritage, Under review.

Strange, G. (1994). "The Arts Centre of Christchurch : Then and Now”. Christchurch, New Zealand: Clerestory Press.

The Arts Centre. (2012). 'Arts Centre Site Remains Closed Following the Canterbury Earthquake of 22 February 2011’, Retrieved 14 Dec 2012, from http://www.artscentre.org.nz/home.

Wight, G. D., Ingham, J. M., and Wilton, A. R. (2007a). "Innovative Seismic Design of a PostTensioned Concrete Masonry House." Canadian Journal of Civil Engineering, 34(11): 13931402. 
Wight, G. D., Kowalsky, M. J., and Ingham, J. M. (2007b). 'Shake Table Testing of Posttensioned Concrete Masonry Walls with Openings' ASCE Journal of Structural Engineering, 133(11): 1551-1559. 